\title{
Screening of bacterial strains for pectate lyase production and detection of optimal growth conditions for enhanced enzyme activity
}

\author{
Monidipta Saha, Rajib S. Rana, Biswanath Adhikary and Sabyasachi Mitra*
}

All India Network Project on Jute and Allied Fibres, ICAR-Central Research Institute for Jute and Allied Fibres, Barrackpore, Kolkata - 700120 (West Bengal), INDIA

*Corresponding author. E-mail: mitrasaby@gmail.com

Received: May 31, 2016; Revised received: October 22, 2016; Accepted: February 4, 2017

Abstract: In the present study, the pectate lyase production by fifty two bacterial strains isolated from ramie grown soils were studied and the strain RDSM01 showed maximum pectate lyase activity. According to sequence homology of Genbank, the strain RDSM01 was identified as Bacillus subtilis (Genbank Accession No. KX035109). Maximum pectate lyase activity of the strain was observed when $1.5 \%(\mathrm{v} / \mathrm{v})$ inoculum was added to the growth medium and was incubated for 48 hours at $34-37^{\circ} \mathrm{C}$ and at $\mathrm{pH} 7.0$. The relative activity of the strain was $19 \%$ higher when apple pectin was used as carbon source compared to citrus pectin. Maximum enzyme production (149.1 - $153.4 \mathrm{IU} /$ $\mathrm{ml}$ ) was recorded when ammonium chloride or ammonium sulphate at $0.4 \%$ concentration was used as nitrogen source. Thus, $B$. subtilis strain RDSM01 possessing high pectate lyase activity may be effectively utilized for removal of gum from ramie fibre, which is primarily made of pectin and hemicellulose.

Keywords: Bacillus subtilis, Enzyme activity, Growth factors, Pectate lyase

\section{INTRODUCTION}

Pectin is a plant polysaccharide primarily made of $\alpha-(1$ -4)-linked D-galacturonic acid and is a component of the middle lamella and primary cell wall thereby contributing to the structure of plant tissues. Pectinolytic enzymes or pectinases degrade pectin through hydrolysis and trans-elimination and also by de-esterification reaction in which the ester bonds between the carboxyl and methyl groups in pectin are hydrolyzed (Uenojo and Pastore, 2007). Among the pectinases, pectate lyase (PEL) had been reported to be used for retting and degumming of bast fibres of flax, ramie, jute and kenaf (Hoondal et al., 2000; Bhattacharya and Paul, 1976; Baracat et al., 1989) as it can effectively degrade the pectin located in the middle lamella and in the primary cell wall of higher plants through trans-eliminative cleavage (Basu et al., 2009).

The crude ramie fibre after mechanical extraction contains approximately $19-30 \%$ gum (w/w) which is primarily made of pectin and hemicelluloses and the gummy substances need to be reduced below $6 \%$ to obtain spinnable fibre (Mitra et al., 2013). The gum in ramie fibre is removed conventionally by treating the fibre with strong (1\%) hot alkali solution which decreases strength of the fibre as well as smoothness of the fibre surface and also pollutes the environment (Ray et al., 2014). The major problems of enzymatic degumming using commercial grade enzymes is the low degumming efficiency, stability of the enzyme as well as high cost of production. In biochemical degumming process, the gum in ramie fibre can be effectively degraded by pectinolytic microorganisms or their enzymes and the fibre can be further treated with mild alkali solution to further reduce the residual gum content in it. Alkaline pectinases produced from Bacillus sp. had been efficiently utilized for degumming of bast fibre of ramie (Boehmeria nivea L.) (Basu et al., 2009; Kapoor et al., 2001) and buel (Grewia optiva) (Kashyap et al.,2001). Microbial retting of jute (Corchorus sp.) using consortium of Bacillus pumillus strains had effectively reduced the retting duration and improved fibre quality over conventional retting (Das et al., 2015). Pectinase enzyme produced by Rhizomucor pusillus has hastened the retting of flax (Linum usitatissimum L.) (Henriksson et al., 1999) while pectinase enzyme from Fusarium $s p$. could effectively remove the pectin and wax impurities from cotton surface and increase the tensile strength of cotton fabric compared to conventionally scoured fabric (Rajendran et al., 2011). Thus the primary objective of the work was to isolate efficient strains of pectinolytic microorganism having high pectate lyase production potential from ramie grown soil and also to optimize the culture conditions for maximum PEL activity by the identified strains.

\section{MATERIALS AND METHODS}

Microorganisms: Fifty two pectinolytic bacterial strains were isolated from the ramie grown soils of four locations belonging to two states of India situated 
in different agro-climatic conditions (Nagaon and Sorbhog of Assam; Coochbehar and Barrackpore of West Bengal). The climate of the locations is subtropical humid in nature, with hot and wet summers and cold winter. The first three locations, namely Nagaon, Sorbhog and Coochbehar are characterized with relatively hot summers $\left(32-35^{\circ} \mathrm{C}\right)$ and cold winter $(7.5$ $-22^{0} \mathrm{C}$ ), relative humidity being $85-97 \%$ and average annual rainfall varying from 1800 to $3300 \mathrm{~mm}$, respectively. The soils are high in organic carbon content $\left(7.3-7.8 \mathrm{~g} \mathrm{~kg}^{-1}\right)$ and acidic in nature $(\mathrm{pH} 5.3-5.8)$ in all the three locations. At Barrackpore, the average annual rainfall is around 1500 to $1600 \mathrm{~mm}$, average maximum and minimum temperature being $31^{\circ} \mathrm{C}$ and $21^{\circ} \mathrm{C}$, respectively with humidity varying from 51 to $93 \%$. The soil is neutral (pH 6.8-7.1) and the organic carbon content is around $6.0 \mathrm{~g} \mathrm{~kg}^{-1}$. The soils were treated in the laboratory with papaya (Carica papaya L.), a good source of pectin, to activate the pectinolytic strains present in those soils.

Bacteria were isolated on the yeast pectin media $(0.5 \%$ $\mathrm{NaCl}, 0.4 \% \mathrm{NH}_{4} \mathrm{Cl}, 1.0 \%$ yeast extract, $0.75 \%$ citrus pectin and $0.005 \%$ cycloheximide at $\mathrm{pH} 8.0$ ) by pour plate method. Pectinolytic bacterial colonies (clear halo around the colonies) were selected, purified by repeated selection of single colonies following streaking on agar plate. Colonies showing maximum halo zone were selected for further study.

Production medium: The liquid medium of yeast pectin (pH- 8.0) was used for bacterial isolation and enzyme production. The yeast pectin media comprised of $0.5 \% \mathrm{NaCl}, 0.4 \% \mathrm{NH}_{4} \mathrm{Cl}, 1.0 \%$ yeast extract, $0.75 \%$ citrus pectin and $0.005 \%$ cycloheximide at $\mathrm{pH} 8.0$.

Screening of isolates for pectinolytic activity: The pectinolytic microbes were isolated from the pectin pre -enriched soil by standard pour plating method. Six distinct colonies among fifty two isolates producing maximum clear halo zone were selected and maintained for further study.

Identification of the selected isolates: The microbial characterization of the selected strain (RDSM01) was carried out by $16 \mathrm{~s}$ rDNA method. The $16 \mathrm{~S}$ rDNA gene was amplified using universal primer $515 \mathrm{~F}$

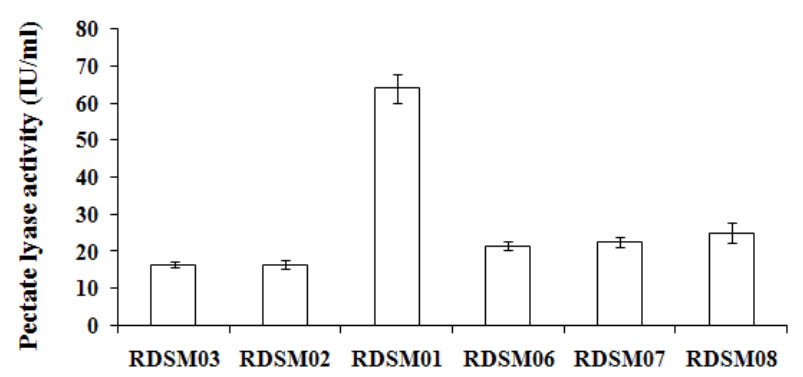

Bacterial strains

Fig. 1. Pectate lyase production from isolated strains in yeast pectin media.
Table 1. Effect of various carbon sources on pectate lyase activity.

\begin{tabular}{ll}
\hline Carbon sources & Pectate lyase activity* $(\mathbf{I U} / \mathbf{m l})$ \\
\hline Sucrose & $37.0 \pm 2.21$ \\
Citrus pectin & $141.0 \pm 9.74$ \\
Apple pectin & $168.5 \pm 6.09$ \\
Glycerol & $35.5 \pm 2.28$ \\
Lactose & $68.5 \pm 7.31$ \\
Xylose & $72.5 \pm 4.19$ \\
Dextrose & $83.0 \pm 5.23$ \\
\hline
\end{tabular}

*: mean values of 10 observations

(GTGCCAGCMGCCGCGGTAA) (Turner et al., 1999)/1381R (CGGTGTGTACAAGRCCYGRGA) (Hodkinson and Lutzoni, 2009). According to the standard methodology, PCR amplification was carried out, the resolved amplified PCR products were gel excised and purified using MinElute Gel extraction kit (Qiagen Inc. USA). The purified PCR products were cloned into pGEM-T Easy vector system (Promega Corp., USA) as per the manufacturers protocol and transformed into competent cells of $E$. coli strain DH5 $\alpha$ using the standard heat-shock method. The white colonies on Xgal-IPTG selection plate were considered as putative positive clones and confirmed for the presence of PCR product through EcoRI Restriction digestion. Three randomly selected positive clones were sequenced from the Xcelris labs limited, India. Sequenced data of cloned fragments were analyzed using BLASTN 2.3.1 (NCBI) and compared to the available NR database.

Enzyme assay: The selected isolates were grown in yeast pectin broth for 48 hours at $35^{\circ} \mathrm{C}$ temperature as stationary / shake $(150 \mathrm{rpm})$ culture. The pectate lyase activity in the culture filtrate was determined by colorimetric method as described by Basu et al. (2009). One unit of activity was defined as the amount of enzyme that caused a change in absorbance of 0.01 under the conditions of the assay.

Optimization studies of PEL production

Optimization of temperature and pH: The optimum temperature for production of pectate lyase enzyme by the selected isolates was determined by incubating the production medium at different temperatures $\left(25^{\circ} \mathrm{C}\right.$, $28^{\circ} \mathrm{C}, 31^{\circ} \mathrm{C}, 34^{\circ} \mathrm{C}, 37^{\circ} \mathrm{C}, 40^{\circ} \mathrm{C}, 43^{\circ} \mathrm{C}, 46^{\circ} \mathrm{C}$ and $\left.50^{\circ} \mathrm{C}\right)$ for 48 hours and enzyme activity was assayed. In another experiment, the $\mathrm{pH}$ of the medium was varied from 2 to 12. The medium was then inoculated with the selected strains at the optimum temperature (determined in the previous experiment) and was incubated at for 48 hours and the PEL activity was measured.

Optimization of inoculum size and incubation time: The effect of inoculum size on PEL production was studied by inoculating the production medium with different amount of inoculum $(1.0 \%, 1.5 \%, 2.0 \%$, $5.0 \%, 7.5 \%, 10 \%, 12.5 \%$ and $15 \%, \mathrm{v} / \mathrm{v})$ at $34^{\circ} \mathrm{C}$ for 48 hours under aseptic conditions and enzyme activity 


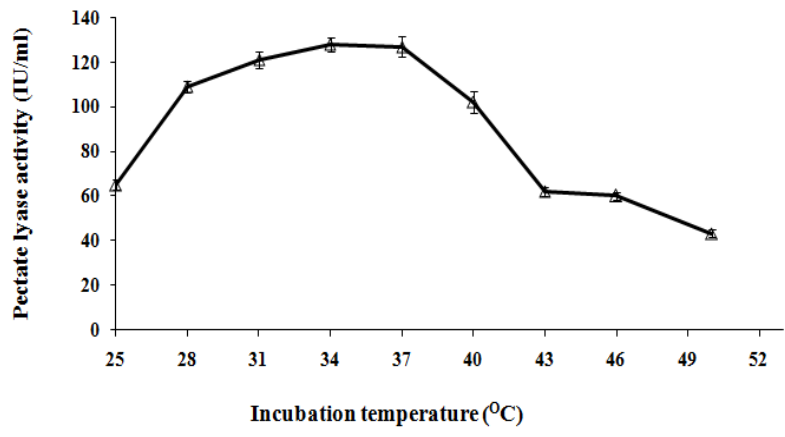

Fig. 2. Effect of temperature on pectate lyase activity.

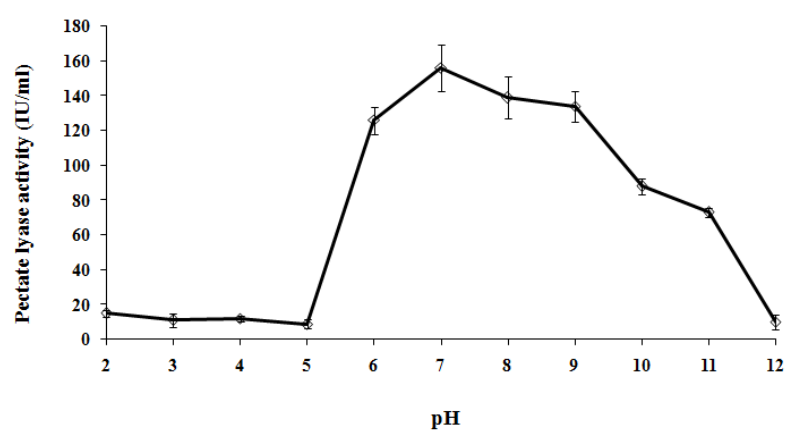

Fig. 3. Effect of $p H$ on pectate lyase activity.

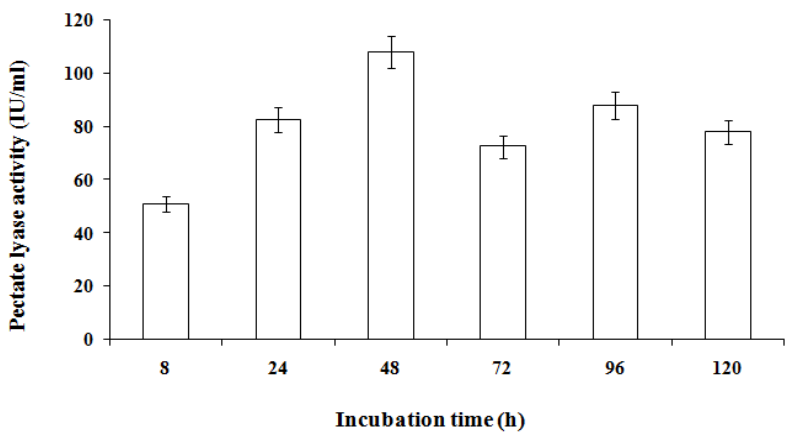

Fig. 4. Effect of incubation time on pectate lyase activity.

was assayed. Similarly, the medium was inoculated with the selected isolate at $34^{\circ} \mathrm{C}$ and was incubated for different time periods (24, 48, 72, 96 and 120 hours) and PEL activity was measured.

Optimization of pectin concentration: The PEL activity was measured at different pectin concentrations $(0.25 \%, 0.5 \%, 0.75 \%, 1.0 \%, 1.25,1.5 \%, 1.75$ and $2.0 \% \mathrm{w} / \mathrm{v})$ to determine the optimum concentration of carbon source in the production medium for getting maximal enzyme production.

Optimization of carbon and nitrogen sources: Various carbon sources, viz. citrus pectin, apple pectin, glycerol, sucrose, lactose, xylose and dextrose were used in the production medium at a concentration of $1.0 \% \mathrm{w} / \mathrm{v}$ to study the effect of carbon source on pectate lyase production. The medium was incubated at $34^{\circ} \mathrm{C}$ for 48 hours and the culture supernatants were assayed for PEL activity.

The production medium was supplemented with different nitrogen sources including ammonium chloride,

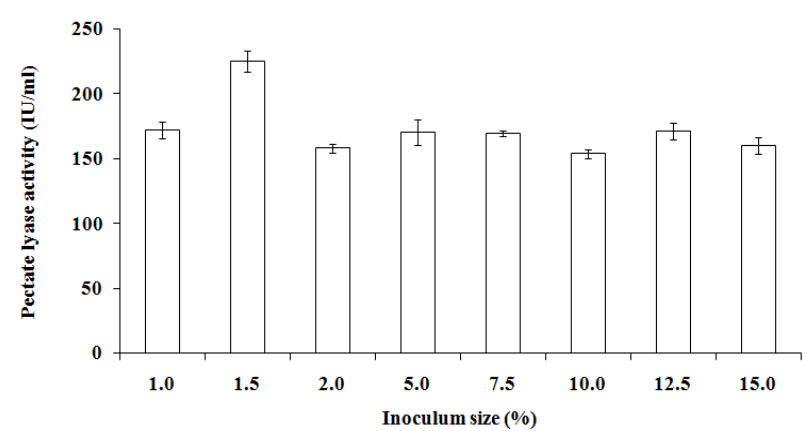

Fig. 5. Effect of inoculum size on pectate lyase activity.

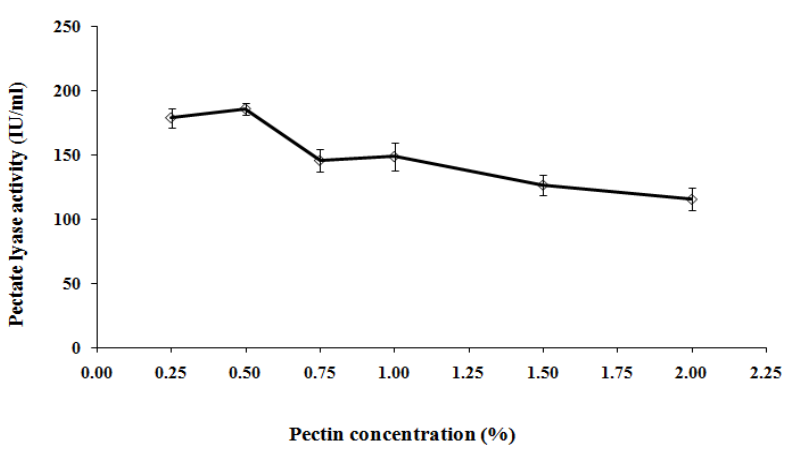

Fig.6.Effect of pectin concentration on pectate lyase activity.

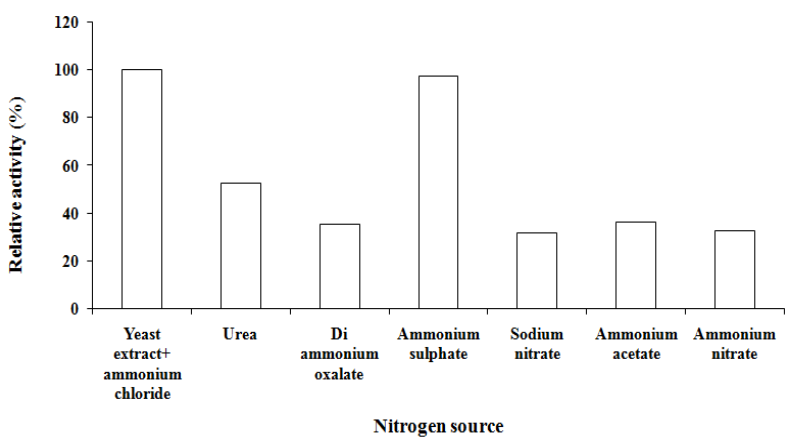

Fig. 7. Effect of various nitrogen sources on relative pectate lyase activity.

urea, di-ammonium oxalate, ammonium sulphate, sodium nitrate, ammonium acetate, ammonium nitrate and yeast extract at a concentration of $0.1 \% \mathrm{w} / \mathrm{v}$. The medium was then incubated at $34^{\circ} \mathrm{C}$ for 48 hours and the PEL activity was determined.

\section{RESULTS AND DISCUSSION}

Six out of fifty two bacterial isolates grown in pectin agar plate were primarily chosen based on the size of halo zone produced around the colonies (data not shown) and pectinolytic activity of these six isolates was studied. The isolate RDSM01 recorded maximum pectate lyase activity $(60 \mathrm{IU} / \mathrm{ml})$ among the six and was finally selected (Fig. 1).

According to a $16 \mathrm{~s}$ rDNA sequence homology analysis from BLASTN 2.3.1 (NCBI) results, the strain (RDSM01) was identified as Bacillus subtilis. The cloned 16s rDNA sequence was deposited in the NCBI with GenBank Accession No. KX035109. Further, the 
optimum condition for production of pectate lyase (PEL) enzyme by the strain RDSM01 was studied. PEL activity of the strain RDSM01 was studied over a temperature range of $25-50^{\circ} \mathrm{C}$ and higher enzyme activity $(127-128 \mathrm{IU} / \mathrm{ml})$ was noticed at temperature range of $34-37^{\circ} \mathrm{C}$ which declined steadily with further increase in temperature (Fig. 2). The reduced PEL activity of the strain at higher temperature may be due to thermal denaturation of the enzyme possibly arising from breaking of non-covalent linkages (Georis et al., 2000; Bhatti et al., 2006). The optimum temperature for pectate lyase production by Bacillus subtilis strain had been reported earlier as $40^{\circ} \mathrm{C}$ (Nasser et al., 1990). The PEL activity of Bacilus subtilis RDSM01 was significantly influenced by the $\mathrm{pH}$ of the growth media and maximum activity was recorded at $\mathrm{pH} 7.0$ (Fig. 3). The reduction in enzyme activity at $\mathrm{pH}$ values, both lower or higher than the optimum $\mathrm{pH}$, could be possibly due to the effect of $\mathrm{pH}$ on the stability of the enzyme (Al Balaa et al., 2014) or due to the alteration in the solubility of the substrates in the medium and their availability for the bacetrial growth (Bruhlman, 1995).

A rapid elevation of extracellular pectate lyase production was observed upto an incubation period of 48 hours and it became almost constant thereafter (Fig. 4). The enzyme production by a micoorganism depends primarily on its growth rate in the substrate and the time for maximal enzyme production in a given medium is a characteristic for that strain (Ramesh and Lonsane, 1990). Higher pectate lyase activity by the strain RDSM01 was recorded when the broth was inoculated with $1.5 \% \mathrm{v} / \mathrm{v}$ inoculum (Fig. 5) and further increase in the inoculum size did not considerably increase enzyme production. The inoculum size of $1.5 \% \mathrm{v} / \mathrm{v}$ could possibly provide adequate biomass during the log phase of the culture thereby leading to higher enzyme secretion by the strain while the decline in enzyme production at higher inoculum levels might be due to the competetion among the bacterial cells for nutrients. Similar relationship between alkaline pectinase secretion and inoculum size was observed with $B$. pumilus dcsr1 by Sharma and Satyanarayana (2012).

The PEL activity of $B$. subtilis RDSM01 was significantly higher at $0.25 \%(179 \mathrm{IU} / \mathrm{ml})$ and $0.5 \%(186 \mathrm{IU} /$ $\mathrm{ml})$ pectin concentration and the extracellular pectinase enzyme production decreased significantly with further increase in pectin concentration (Fig. 6). The result indicated enzymatic repression possibly due to the presence of some pectin degradation products acting as enzyme inhibitors at higher substrate concentration (Teixeira et al., 2000). Similar inhibition of enzyme activity at higher pectin content was reported in pectinase production by Aspergillus niger MTCC 281 by using natural substrates i.e., wheat and corn flour (Palaniyappan et al., 2009).

Maximum enzyme secretion by the strain (168.5 IU/ $\mathrm{ml}$ ) was observed when apple pectin was used as carbon source and the relative activity was $19 \%$ higher as compared to that of citrus pectin (Table 1). This suggests that the organism utilized apple pectin more efficiently compared to other carbon sources. The low PEL activity (relative activity of $25-59 \%$ ) of Bacillus subtilis RDSM01 in sucrose, lactose, xylose, dextrose and glycerol indicated the possible susceptibility of the strain to catabolic repression while utilizing these carbon sources. Efficient utilization of citrus and apple pectin by Bacillus sphaericus as compared to other sugars as carbon sources was also observed earlier (Jayani et al., 2010).

Among the different nitrogen sources used, relative activity of the strain was higher in $0.4 \%$ ammonium chloride (control) and $0.4 \%$ ammonium sulphate $(97.2$ - $100 \%)$ while it was quite low $(31.5-52.7 \%)$ in other nitrogen sources (Fig. 7). The results can be explained on the basis of possible growth promotion of $B$. subtilis RDSM01 due to addition of ammonium chloride or ammonium sulphate in the medium thereby resulting in higher production of pectate lyase by the strain. The results corroborated the earlier findings of Kashyap et al. (2003).

\section{Conclusion}

The pectinolytic bacterial strain Bacillus subtilis RDSM01 isolated from soil of Barrackpore, West Bengal, India showed higher pectate lyase activity when incubated at $34-37^{\circ} \mathrm{C}$ temperature for 48 hours and at $\mathrm{pH}$ 7.0. The strain prefered apple pectin as carbon source and the optimal pectin concentration in the growth medium was found to be $0.5 \%$. Maximum enzyme production was observed when ammonium chloride or ammonium sulphate at a concentration level of $0.4 \%$ was used as nitrogen source in the medium. Since Bacillus subtilis RDSM01 had shown considerably higher pectate lyase activity and the optimum conditions for maximum enzyme production had been determined, this strain can be effectively used for removal of gum of ramie fibre which is primarily made of pectin and hemicellulose.

\section{ACKNOWLEDGEMENTS}

The authors acknowledge Ministry of Textile, Government of India for providing financial support for this research programme under Technology Mission of Jute, Mini Mission I. The authors are also grateful to Director, ICAR-Central Research Institute for Jute and Allied Fibres, Barrackpore, Kolkata, West Bengal 700120 , India for providing the necessary infrastructures for conducting the research programme successfully. This work has also been supported by Indian Council of Agricultural Research (ICAR), India.

\section{REFERENCES}

Al Balaa, B., Esmail, B. R. and Yazaji, S. (2014). Purifica- 
tion and characterization of an extracellular alkaline pectate lyase from Bacillus subtilis BPLSY1. Bulgarian J. Agril. Sci., 20: 193-198

Baracat, M. C., Valentin, C., Muchovej, J. J. and Silva, D.O. (1989). Selection of pectinolytic fungi for degumming of natural fibres. Biotechnol Lett., 11: 899-902

Basu, S., Saha, M. N., Chattopadhyay, D. and Chakrabarti, K. (2009). Large-scale degumming of ramie fibre using a newly isolated Bacillus pumilus DKS1 with high pectate lyase activity. J. Ind Microbiol Biotechnol., 236: 239-245

Bhattacharya, S. K. and Paul, N. B. (1976). Susceptibility of ramie with different gum contents to micrfobial damage. Curr. Sci., 45: 417-418

Bhatti, H. N., Ashger, M., Abbas, A., Nawaz, R. and Sheikh, A. (2006). Studies on kinetics and thermostability of a novel acid invertase from Fusarium solani. J. Agril. Food Chem., 54: 4617-4623

Bruhlman, F. (1995). Purification and characterization of an extracellular pectate lyase from an amycolata sp. Appl. Environ. Microbiol., 61: 3580-3585

Das, Suparna, Majumdar, B. and Saha, A. R. (2015). Biodegradation of plant pectin and hemicelluloses with three novel Bacillus pumilus strains and their combined application for quality jute fibre production. Agril. Res., 4: 354-364

Georis, J., Esteves, F. L., Brasscur, J. L., Bougnet, V., Devreese, J. L. B. and Gianotta, F. (2000). An additional aromatic interaction improves the thermostability and thermophilicity of a mesophilic family xylanase: Structural and molecular study. Prot. Sci., 9: 466-475

Henriksson, G., Akin, D. E., Slomczynski, D. and Eriksson, K.E.L. (1999). Production of highly efficient enzymes for flax retting by Rhizomucor pusillus. J. Biotechnol., 68:115-123

Hodkinson, B.P. and Lutzoni, F. (2009). A microbiotic survey of lichen-associated bacteria reveals a new lineage from the Rhizobiales. Symbiosis, 49: 163-180

Hoondal, G. S., Tiwari, R.P., Tiwari, R., Dahiya, N. and Beg, Q. K. (2000). Microbial alkaline pectinases and their applications: a review. Appl. Microbiol. Biotechnol., 9: 409-418

Jayani, R. S., Shukla, S. K. and Gupta, R. (2010). Screening of bacterial strains for polygalacturonase activity: Its production by Bacillus sphaericus (MTCC 7542) Enzyme Res. http://dx.doi.org/10.4061/2010/306785.

Kapoor, M.,Beg,Q.K.,Bhusan, B., Singh,K.,Dadhich, K.S. and Hoondal,G.S. (2001).Application of an alkaline and thermosable polygalacturonase from Bacillus sp. Mgmep-2 in degumming of ramie (Boehmeria nirea) and sunnhemp (Crotalaria juncea) vast fibres. Process Biochem., 36:803-807
Kashyap, D. R., Soni, S. K. and Tewari, R. (2003). Enhanced production of pectinase by Bacillus sp. DT7 using solid state fermentation. Bioresource Technol., 88: 251-254

Kashyap, D. R., Vohra, P., Soni, S. K. and Tewari, R. (2001). Degumming of buel (Grewia optira) vast fibres by pectinolytic enzyme from Bacillus sp.DT7. Biotecnol.Lett., 23:1297-1301

Mitra, S., Satya, P. and Mahapatra, B. S. (2013). Allied fibre crops. In: Textbook of Field Crops Production - Commercial Crops Vol. II. Indian Council of Agricultural Research, New Delhi, India, pp. 377-398.

Nasser, W., Chalet, F. and Robert-Baudouy, J. (1990). Purification and characterization of extracellular pectate lyase from Bacillus subtilis. Biochemie., 72: 689-695.

Palaniyappan, M., Vijayagopal, V., Viswanathan, R. and Viruthagiri, T. (2009). Screening of natural substrates and optimization of operating variables on the production of pectinase by submerged fermentation using $A s$ pergillus niger MTCC 281. African J. Biotechnol., 8:682-686

Rajendran, R., Sundaram, S. K., Radhai, R. and Rajapriya, P. (2011). Bioscouring of cotton fabrics using pectinase enzyme its optimization and comparison with conventional scouring process. Pakistan J. Biol. Sci., 14:519525

Ramesh, M. V. and Lonsane, B.K. (1990). Production of bacterial thermostable $\alpha$-amylase by solid-state fermentation: a potential tool for achieving economy in enzyme production and starch hydrolysis. Advances Appl. Microbiol., 35: 1-56

Ray, D.P., Banerjee, P., Mondal, S. B., Satya, P. and Mitra, S. (2014). Ramie degumming through novel chemical process. In: Jute and Allied Fibres: Issues and Strategies. The Indian Natural Fibre Society, Kolkata, India, pp. $15-20$

Sharma, D.C. and Satyanarayana, T. (2012).Biotechnological potential of Agro residues for economical production of thermoalkali stable peectinase by Bacillus pimilus desr 1 by solid-state fermentation and its efficacy in the treatment of ramie fibres. Enzyme Res., http:// dx.doi.org /10.1155/2012/281384

Teixeira, M. F. S., Filho, J. L. L. and Durán, N. (2000). Carbon sources effect on pectinase production from Aspergillus japonicas 586. Brazillian J. Microbiol., 31:286-290

Turner, S., Pryer, K.M., Miao, V.P.W. and Palmer, J. D. (1999). Investigating deep phylogenetic relationships among cyanobacteria and plastids by small subunit rRNA sequence analysis. J. Eukaryotic Microbiol., 46: $327-338$ 